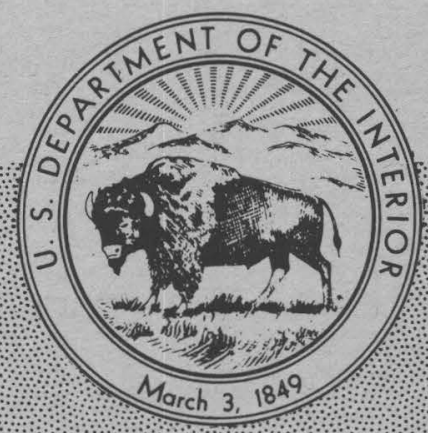

\title{
GROUND-WATER SUPPLY OF THE
}

\section{MEMPHIS AREA}

Prepared in cooperation with the

Memphis Light, Gas, and Water Division 



\section{UNITED STATES DEPARTMENT OF THE INTERIOR}

FRED A. SEATON, Secretary

GE O LOGICAL SURVEY

Thomas B. Nolan, Director

GEOLOGICAL SURVEY CIRCULAR 408

\section{GROUND-WATER SUPPLY OF THE MEMPHIS AREA}

By James H. Criner and Clarence A. Armstrong

Prepared in cooperation with the

Memphis Light, Gas, and Water Division 


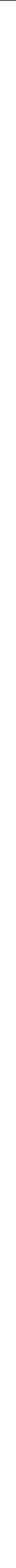




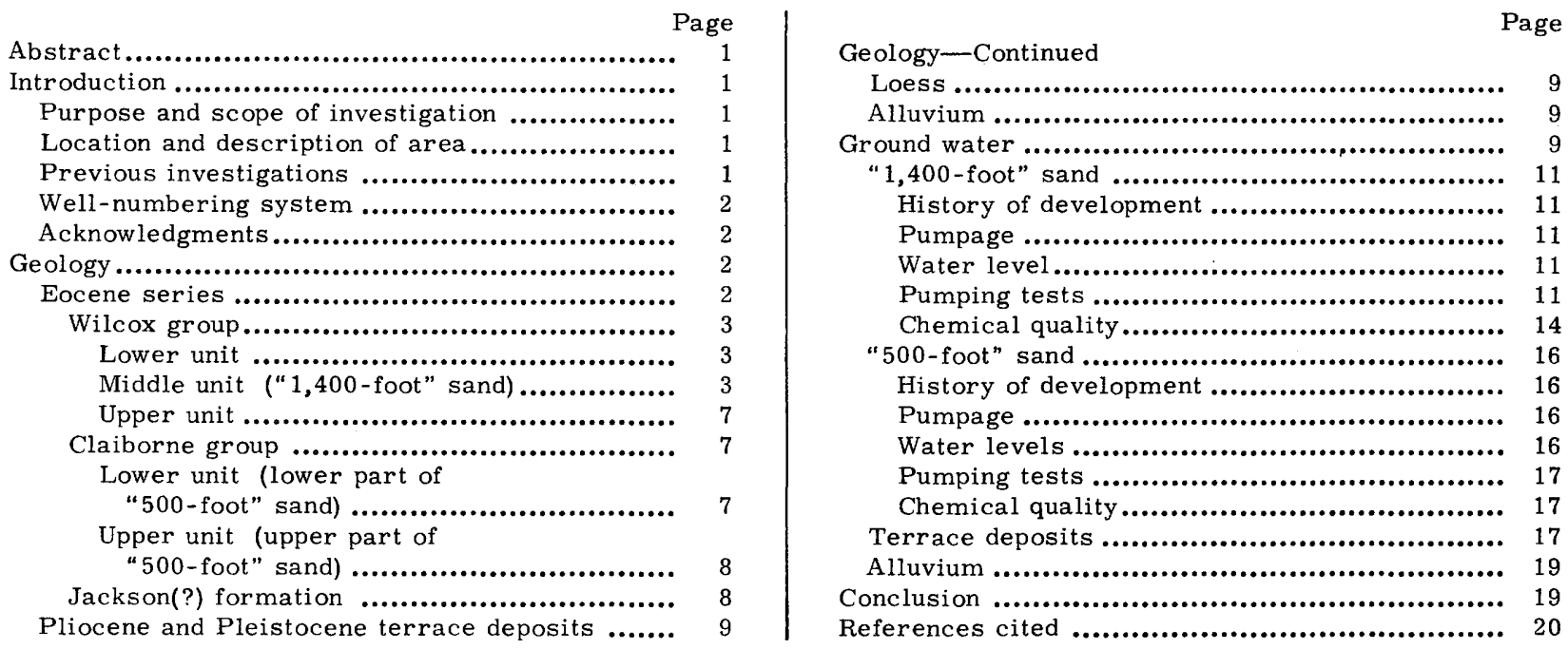

\section{ILLUSTRATIONS}

Plate 1. Map of the Memphis area showing location of observation wells, test holes, and lines of cross sections

Figure 1. East-west generalized geologic section

2. North-south generalized geologic section

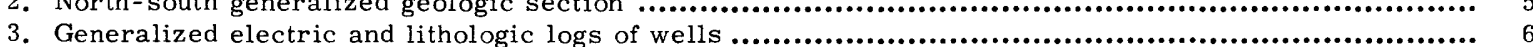

4. Graph showing water production from the well fields furnishing the Memphis public water

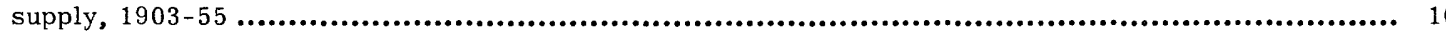

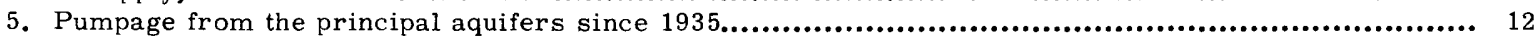

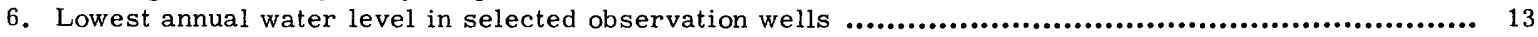

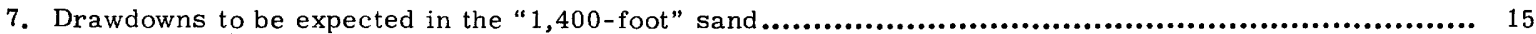

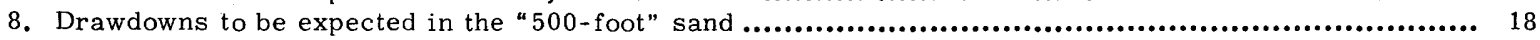

\section{TABLES}

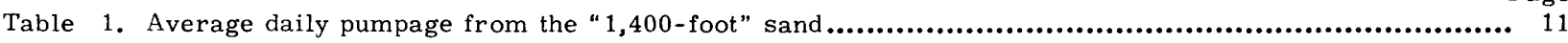

2. Typical chemical analyses of water from the " 1,400 -foot" sand ............................................. 14

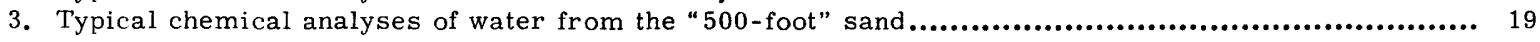




\title{
GROUND-WATER SUPPLY OF THE MEMPHIS AREA
}

\author{
By James H. Criner and Clarence A. Armstrong
}

\section{ABSTRACT}

The Memphis area of this report comprises about 1,000 square miles of the part of the Gulf Coastal Plain known as the Mississippi embayment. It includes Shelby County, Tenn., and small parts of Arkansas and Mississippi. The area is underlain surficially by clay, silt, sand, and gravel of Recent, Pleistocene, and Pliocene age, and these materials are underlain in turn by sand and interbedded lignite, clay, and silt of Eocene age; clay and sand of Paleocene age; and sand, clay, and chalky limestone of Cretaceous age. Only units of Eocene age and younger are discussed in this report.

Most of the water used in the area is derived from the "500-foot" sand of the Claiborne group and the "1,400-foot" sand of the Wilcox group, both of Eocene age. Several small industrial supplies and numerous domestic supplies are obtained from the terrace deposits of Pliocene and Pleistocene age. In 1955 the average daily pumpage of water from all sources was about 137 million gallons, 90 percent of which was obtained from the " 500 -foot" sand. Municipal pumpage accounted for about $60 \mathrm{mgd}$ (million gallons per day), industrial pumpage about 70 , and domestic and irrigation pumpage about 7 .

Water levels in wells penetrating the principal aquifers have declined continuously since pumping began. During World War II the decline of water levels in the " 500 -foot" sand was more rapid than in previous years and was greatest in an area in north Memphis where pumping was concentrated. The addition of the Thomas Allen pumping station in southwest Memphis in 1953 had the effect of decentralizing pumping and caused a general decrease in the rate of decline. Generally, pumping from the " 1,400 -foot" sand has increased like that from the " 500 -foot" sand, but at a lower rate.

The aquifers are recharged mainly by precipitation in areas where they crop out, and by percolation or leakage from adjacent rocks; but the Mississippi River probably contributes some water to the " 500 -foot" sand and the terrace deposits.

The quality of the water from the " 500 -foot" and " 1,400 -foot" sands is very good. The only undesirable constituents in these waters in appreciable quantities are iron and carbon dioxide; both, however, can be easily removed by aeration and filtration. Water from the terrace deposits is very hard.

Records of more than 300 wells in the area, as well as logs and geologic data collected outside the area, were tabulated for study and evaluation. Well and geologic data have been collected continuously by the
U. S. Geological Survey since 1940. Records collected earlier by the Memphis Light, Gas, and Water Division and private well owners were made available to the writers.

\section{INTRODUCTION}

\section{Purpose and Scope of Investigation}

In 1940 the U. S. Geological Survey, in cooperation with the Memphis Light, Gas, and Water Division, began a program of water-level measurements in the Memphis area to supplement previous water-level records from wells 3-A and 5-193. The program was enlarged in 1943 and an investigation of the ground-water resources and conditions in the Memphis area was begun. This progress report is the third to be released since 1943. The first was by Kazmann (1944) and the second by Schneider and Cushing (1948).

This report presents and interprets the groundwater data that have been collected since publication of the last progress report and incorporates the pertinent facts that were given in that report and in the preceding report. Both are now out of print.

The investigation of the Memphis area is under the general supervision of A. N. Sayre, chief of the Ground Water Branch, U. S. Geological Survey, and E. M. Cushing, district engineer for Tennessee.

\section{Location and Description of Area}

The Memphis area, as considered in this report, comprises about 1,000 square miles. It forms a rectangle lying along the Mississippi River and includes Shelby County, Tenn., and small parts of Arkansas and Mississippi. Plate 1 shows the location of the Memphis area and the location of observation wells, test wells, and lines of cross sections.

The population of the area in 1955 was about 600,000 . The Chamber of Commerce estimated that as of January 1, 1956, the population of Memphis was 451,850 and that of Shelby County was 530,100.

Memphis is the largest industrial center in Tennessee and is the largest city in the world using artesian water for public supply.

\section{Previous Investigations}

Among the earliest reports relating to ground water in the area was one written by Safford (1890). Glenn 
(1906) wrote a report on the ground-water conditions of this region. Wells (1931) wrote a preliminary report on the artesian water supply of Memphis and a reconnaissance report on the ground-water resources of western Tennessee (1933). Stearns and Armstrong (1955) wrote a report on the post-Paleozoic stratigraphy of western Tennessee and adjacent portions of the upper Mississippi embayment.

Records of water levels in observation wells have been published in Water-Supply Papers $817,840,845$, $886,907,937,945,987,1017,1024,1072,1097,1127$, $1157,1166,1192,1222,1266,1322$, and 1405 of the U. S. Geological Survey under the title "Water Levels and Artesian Pressures in Observation Wells in the United States, Part 2, Southeastern States." Waterlevel measurements made from April 1927 to March 1931 are presented graphically in Water-Supply Paper 656.

\section{Well-Numbering System}

The wells of the Memphis area are numbered according to a system in which each well number is made up of three parts, the first and second of which are separated by a colon and the second and third by a hyphen. The first part represents the county in which the well is situated, the second is the number assigned the owner or well field, and the third is the number of the well itself. The first part necessitated numbering all the counties in the State in alphabetical order, starting with Anderson County as 1, Bedford County as 2 , and so on. To provide for the second part, the owners or the well fields were assigned numbers in consecutive order as the wells were recorded by the U. S. Geological Survey. The third part, the number of the well, corresponds to the number assigned the well by the owner. For example, the number 79:7-17 indicates county 79, which is Shelby County; well field 7, which is the Parkway field of the Memphis Light, Gas, and Water Division; and well 17 in that field as. numbered by the owner. The Auction Avenue well field of the Memphis Light, Gas, and Water Division is part of the earliest water-distribution system for Memphis. The water of about 100 wells flowed through tunnels into a so-called "wet-well." This field is designated 3 in Shelby County, and the shafts that were used to inspect the tunnels and drifts of that field, 26 in all, have been lettered to differentiate them from the wells. Shaft number 79:3-A is used as an observation well. Oil tests in the Memphis area were not assigned location numbers; the numbers given by the owners are used throughout this report. The well numbers on maps and hydrographs in this report are shown without the county number, as all the wells are in Shelby County.

\section{Acknowledgments}

The writers thank the many members of the Memphis Light, Gas, and Water Division for their cooperation and assistance, especially Major Thomas H. Allen, president; Mr. C. M. McCord, past director, and $\mathrm{Mr}$. J. J. Davis, director of the Water Division; Messrs. A. J. Rumley, W. G. Lanham (deceased), and C. H. Pou (deceased). They also thank the Layne-Central Co., the Carioss Well Supply Co., and the Watson Co. for furnishing drillers' logs of various wells within the area; and also the owners of the wells, who gave information regarding their wells and furnished pumpage records.

The assistance of Dr. L. M. Graves, director, and Mr. W. M. Craddock, of the Memphis and Shelby County Health Department, in locating a number of wells which could be used in the water-level measurement program also is acknowledged.

\section{GEOLOGY}

Several times during Late Cretaceous and Tertiary time the region extending from Cairo, Ill., to the Gulf of Mexico and from Little Rock, Ark., east to the Tennessee River was a iowland or an arm of the sea. Several thousand feet of gravel, sand, silt, lignite, clay, chalk, and limestone were deposited in this shallow geosyncline, which has been termed the Mississippi embayment. The formations of the embayment dip at rates of 10 to 35 feet per mile from the outer edges toward the axis, which coincides approximately with the present course of the Mississippi River. They also dip south, at a lower angle.

Memphis is near the center of the upper embayment. The strata underlying the city dip generally westward because the axis of the embayment in this vicinity is west of the Mississippi River. (See fig. 1.) Strata older than Eocene are not described in this report because no ground water is pumped from them. The strata of Eocene, Pliocene, Pleistocene, and Recent age furnish all the ground water to the area; consequently, many wells have been drilled into these formations and much information has been obtained about them.

The approximate depths and thicknesses of Eocene and younger formations in the area are shown in east-west (fig. 1) and north-south (fig. 2) generalized geologic cross sections. Electric and lithologic logs were used to determine formation and unit boundaries.

\section{Eocene Series}

Below is a generalized chart of geologic units of Eocene age and younger underlying the Memphis area, compiled from electric and lithologic logs of wells. The three lowermost units are presumed to be part of the Wilcox group because they lie below the Meridian sand member of the Tallahatta formation as shown on cross sections by Brown (1947, pl.4). Figure 3 shows generalized electric and lithologic logs of wells in the area. The Wilcox and Claiborne groups may be differentiated in the subsurface at Memphis, but no attempt is made in this report to correlate them with formations of the subsurface in other areas. Detailed surface mapping of the Tertiary rocks and lithologic and electric logs of additional wells are needed before any positive correlations can be made.

The rocks of the Eocene series in western Tennessee strike north-northeast and dip westward 10 to 35 feet per mile. Schneider and Blankenship (1950) have indicated that Eocene sediments are about 
Generalized chart of Cenozic rocks underlying the Memphis area

\begin{tabular}{|c|c|c|c|c|c|}
\hline Sy stem & Series & Group & Formation or unit & $\begin{array}{l}\text { Thickness } \\
\text { (feet) }\end{array}$ & Description \\
\hline \multirow[t]{2}{*}{ Quaternary } & Recent & & Alluvium & $0-200$ & Alluvial sand, clay, and gravel. \\
\hline & Pleistocene & & Loess & $0-100$ & Wind-deposited silt. \\
\hline \multirow[t]{3}{*}{$\longrightarrow$ ? } & $\begin{array}{l}\text { Pleistocene } \\
\text { and Pliocene }\end{array}$ & & $\begin{array}{c}\text { Terrace } \\
\text { deposits }\end{array}$ & $0-160$ & Alluvial sand and gravel. \\
\hline & \multirow{5}{*}{ Eocene } & & $\begin{array}{l}\text { Jackson(?) } \\
\text { formation }\end{array}$ & $56-300$ & $\begin{array}{l}\text { Gray, bluish-gray, greenish-gray, and } \\
\tan \text { clay; minor amounts of lignite } \\
\text { and fine sand. }\end{array}$ \\
\hline & & Claiborne & $\begin{array}{l}\text { Upper unit } \\
\text { (upper part of } \\
\text { " } 500 \text {-foot" sand) }\end{array}$ & $190-400$ & $\begin{array}{l}\text { Fine to coarse sand and minor amounts } \\
\text { of lignite and greenish-gray and tan } \\
\text { clay and silt. }\end{array}$ \\
\hline \multirow[t]{3}{*}{ Tertiary } & & \multirow{3}{*}{ Wilcox } & Upper unit & $200-395$ & $\begin{array}{l}\text { Gray, greenish-gray, and brown } \\
\text { carbonaceous clay. Thin lignite and } \\
\text { fine sand locally. }\end{array}$ \\
\hline & & & $\begin{array}{l}\text { Middle unit } \\
\text { (" } 1,400 \text {-foot" sandi) }\end{array}$ & $165-300$ & Fine to medium sand. \\
\hline & & & Lower unit & $\left|\begin{array}{c}190-250 \\
\text { where known }\end{array}\right|$ & $\begin{array}{l}\text { Gray, greenish-gray, and brown } \\
\text { carbonaceous clay, and lignite; sandy } \\
\text { near top. }\end{array}$ \\
\hline
\end{tabular}

\section{Wilcox Group}

Lower unit.- The lowest unit of the Wilcox group is the lowermost Eocene in the Memphis area. Some writers have considered this unit to be of Paleocene age, but in this report it is considered to be of Wilcox age. It is relatively impermeable and forms the lower confining layer for water in the overlying middle unit ("1,400-foot" sand). The lower unit consists mainly of gray to greenish-gray silty clay, brown carbonaceous clay, and thin interbedded gray silt, grading upward into gray silt containing thin clay lenses and lenses of very fine sand. Lignite is common in this unit, generally in beds not more than a few inches thick. Muscovite also is common but is more prevalent in the upper part of the unit, where it is associated with the sandy lenses.

The lower unit of the Wilcox group is about 190 feet thick in observation well 24:10-1 near Braden, Fayette County; about 250 feet thick in Crumpler oil test 1 southeast of Memphis, Shelby County; and about 230 feet thick in the Lion Oil Refining Co., Bateman oil test 1 just 3.5 miles south of Millington, Shelby County. No additional detailed lithologic logs of wells that have completely penetrated the unit in the Memphis area are available, but several wells have been drilled 30 feet or more into it.

The apparent westward dip of the upper surface of the lower unit is about 30 feet per mile in Memphis.
In other areas the dip may be more or less than this because the unit apparently thins toward the north and east.

The laminated clay and the fresh-water plant spores in the lower unit of the Wilcox group indicate that the materials composing this unit probably were deposited in large fresh-water lakes or swamps, or in lagoons that gradually filled to form large tidal flats and were later covered by the sandy deposits of the overlying unit.

Middle unit ("1,400-foot" sand). - The middle unit of the Wilcox group is an important aquifer known in the Memphis area as the "1,400-foot" sand. It has not been studied in any detail beyond the Memphis area, and its area of outcrop has not been determined. Brown (1947) believed that this sand could be recognized in the subsurface 80 miles south of Memphis. It is also recognizable in the subsurface of places about 15 miles east and 35 miles northeast of Memphis. It has been tentatively recognized in the subsurface about 95 miles north of Memphis and also 30 miles west.

In the Memphis area the "1,400-foot"sand dips westward about 25 feet per mile. If the sand continues eastward, at this rate of dip it should crop out a few miles west of the outcrop between the Midway and Wilcox contact, about 60 miles due east of Memphis. In that area there is an exposure of sand that may be 


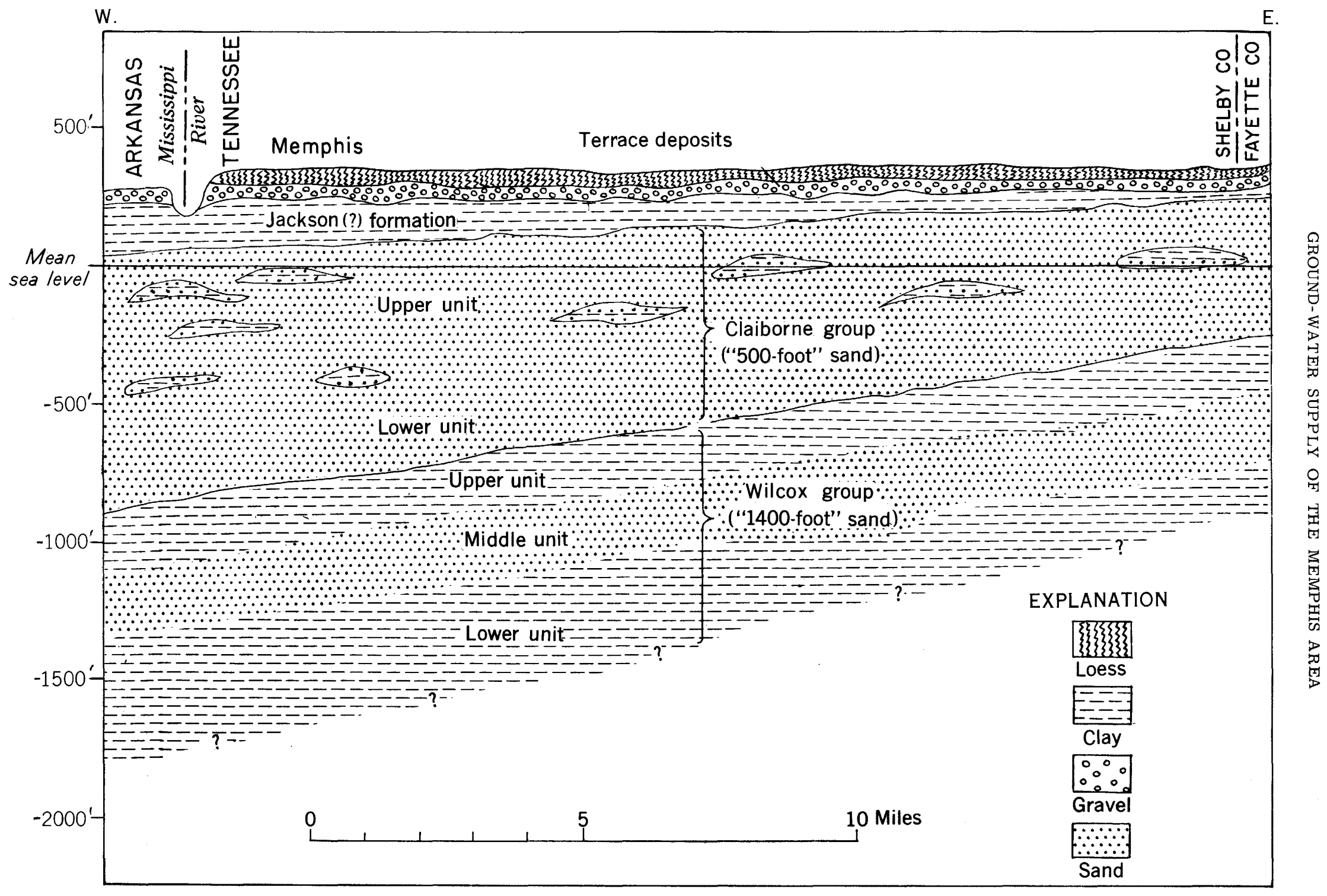

Figure 1.-East-west generalized geologic section. 


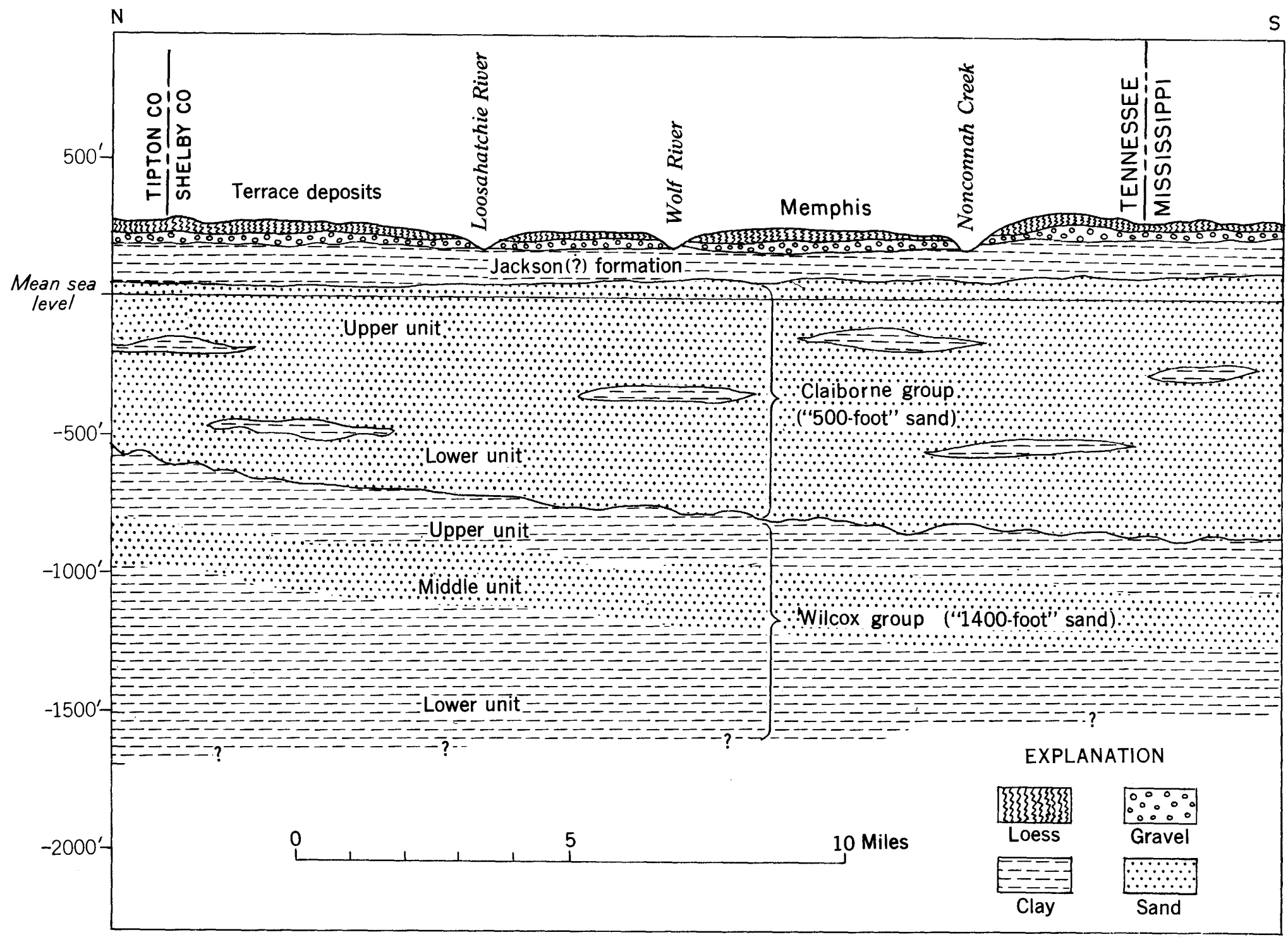




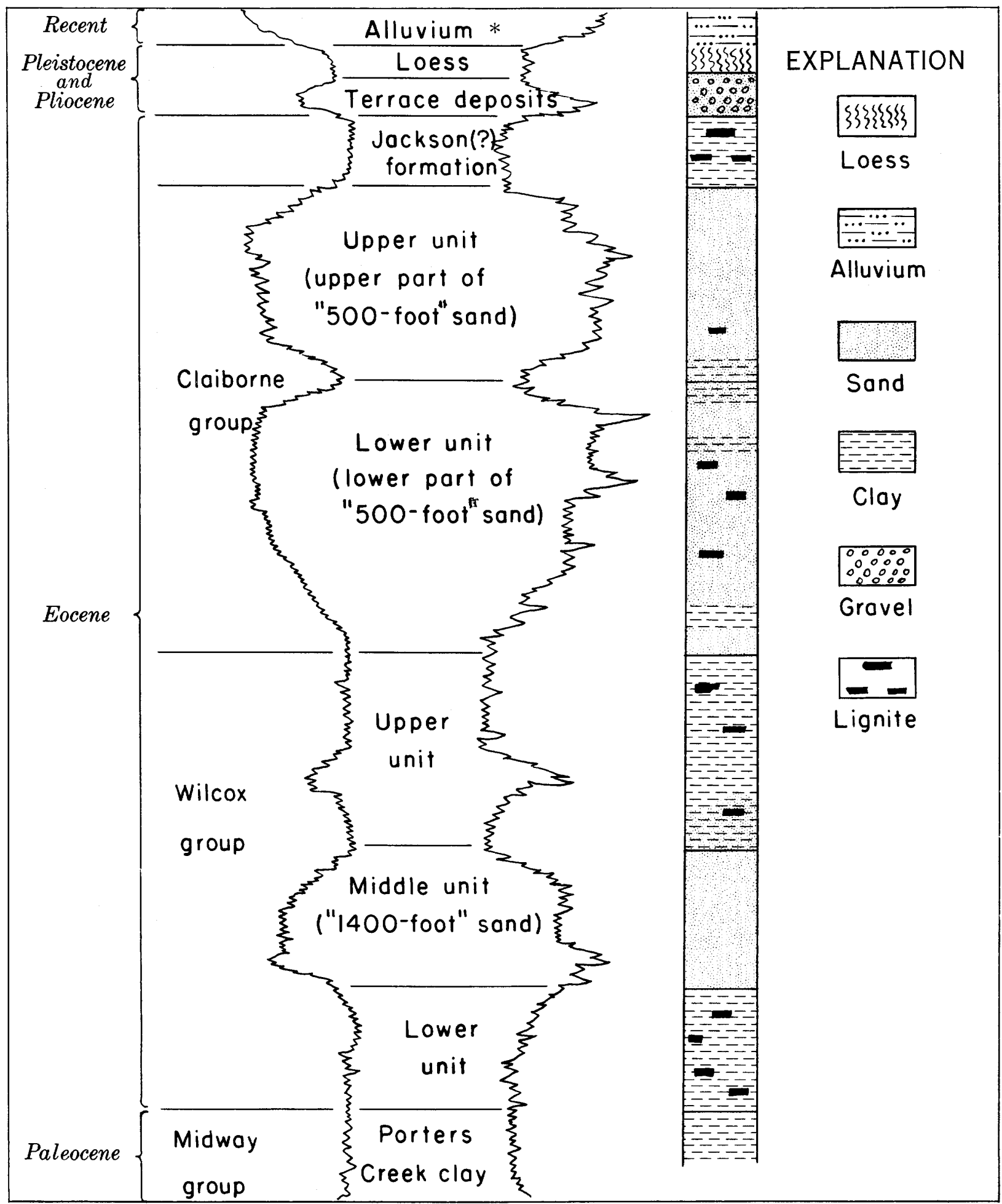

* Topographically the loess is higher than the alluvium 
the "1,400-foot" sand. Drillers' logs of wells near Whiteville, Hardeman County, and near Jackson, Madison County, suggest that the "1,400-foot" sand continues to the surface. However, a cross section by Schneider and Blankenship (1950) indicates that the Wilcox group may be overlapped by the Claiborne group. More recent subsurface information indicates that the sand may crop out also 100 to 125 miles north of Memphis, but additional data are needed before this evidence can be substantiated.

In the Memphis area the "1,400-foot" sand consists predominantly of unconsolidated well-sorted fine- to medium-grained subangular to angular micaceous quartz sand. A few well logs in this sand show thin beds of sandy clay or silty sand, but these beds are probably lenses of no great extent.

Drillers' logs and electric logs indicate that the " 1,400 -foot" sand varies considerably in thickness within short distances, becoming thicker toward the axis of the embayment. In the Allen well field in southwest Memphis the unit ranges in thickness from 175 to 203 feet. It is 203 feet thick in the subsurface in east Memphis and 210 feet thick in the subsurface in north Memphis. The greatest thickness of this sand in the Memphis area is about 300 feet, reported in the Ramsey Petroleum Co., Sanderson test well 1, Crittenden County, Ark.

Histograms of data obtained from 22 samples from 8 wells in the Memphis area are most nearly like those of the typical beach or dune-sand histograms of Krumbein and Sloss (1951), who state, "Shallow epeiric seas, continuously advancing on a slowly submerging land, bring the littoral environment with them." This type of environment develops a sheet sand which is well sorted and similar to a beach deposit. Lignite fragments and muscovite flakes in the "1,400-foot" sand suggest that it was deposited in water. The sorting and extent of the deposit indicate that it is a shallow-water marine sand.

Upper unit.--In this report the upper unit of the Wilcox group includes only the clay and silt that lie above the "1,400-foot" sand. It is considered to be the topmost part of the Wilcox group on the basis of an extension of Brown's (1947) cross section, which shows basal Claiborne directly overlying it. No other indication of the age of this unit has been found.

The dip and strike of the upper unit have not been calculated because its top is too irregular. Some clay and silt assigned to the upper part of it may actually be lenses in the lower part of the "500-foot" sand, but there is no evidence other than a sand and clay contact that can be used to separate the upper unit of the Wilcox group from the "500-foot" sand.

In the Sheahan well field in east Memphis, the upper unit ranges in thickness from 200 to 395 feet. The lignite beds and the fresh-water plant spores and seeds suggest swamp deposition; however, the glauconite and the green-colored clays indicate marine deposition. Marine and nonmarine conditions, if they existed concurrently, would have caused deposition of a very complex unit.

\section{Claiborne Group}

Lower unit ("lower part of 500-foot" sand). - The lower unit of the Claiborne group is the lower part of the "500-foot" sand of the Memphis area. A body of clay and sand has been included arbitrarily at its base. An apparent west-northwest dip of 10 feet per mile was calculated by using the highest elevations of the bottom of the lower unit in the area.

In the past, drillers have thought that they could not make a good well in the "500-foot" sand at a depth greater than 600 feet below the land surface. Consequently, information on the lower unit is scarce, and possibly two aquifers have been overlooked. The log of well 79:7-44 in the Parkway well field shows 157 feet of medium and coarse sand between 890 and 1,047 feet below the land surface. According to this $\log$, the sand is overlain by 80 feet of clay. The log of B. A. Murrelle, Horton oil test 1, near Benjestown, Shelby County, shows 170 feet of medium and coarse sand and 80 feet of overlying clay. The log of the Lion Oil Refining Co., Bateman oil test 1, south of Millington, shows 160 feet of medium and coarse sand overlain by 60 feet of silt. The log of well 79:8-62 in the Sheahan well field shows 142 feet of sand from 748 to 890 feet below the land surface. This sand is overlain by 85 feet of clay. The log of well 79:8-60, 600 feet southwest of well 79:8-62, shows 105 feet of sand below 780 feet, and well 79:8-65, about 500 feet west of well 79:8-62, has 65 feet of sand below 796 feet. These sands are overlain by about 50 feet of clay. They may be part of a system of "shoestring sands" that extend generally north and south, but available information is not sufficient to outline their extent. They are not present in test well 24:10-1 or in the 1,500-foot test wells in the Allen well field in southwest Memphis. Several wells in the Parkway well field in north Memphis and in the Sheahan well field in east Memphis do not penetrate any sand at, or near, the same position as in the other wells mentioned.

If these deposits of sand are part of a system of "shoestring" sands, it is possible that they may be connected with other parts of the "500-foot" sand. On the other hand, it is also possible that water could be pumped from wells screened in these lower sands without materially decreasing the pressure head in the overlying portions of the " 500 -foot" sand, at least immediately. The Memphis Light, Gas, and Water Division screened well 79:8-61 in this sand, but the well was abandoned after $31 / 2$ years because the drawdown was considered to be excessive.

In the Allen well field in southwest Memphis the upper part of this unit consists of well-sorted finegrained to very fine gray micaceous quartz sand and scattered thin beds of lignite and clay. Sieve analyses of washed samples generally show these samples to be 60 to 70 percent fine sand and 20 to 25 percent very fine sand. In the Parkway well field fine sand and clay layers have been logged but not with enough detail to determine the contact between the upper and lower units of the Claiborne group. The logs of the deep wells in the Sheahan well field show sand but do not indicate the grain size. Many of the shallow test holes in this field were stopped after penetrating as much 
as 100 feet of fine sand. In the Getwell well field in southeast Memphis, several wells were stopped in the fine sand or penetrated only a few feet of it. The fine sand in the Allen well field, in the B. A. Murrelle, Horton oil test 1, in well 79:8-85 in the Getwell field, and in six test wells in the proposed well field near Bartlett, Shelby County, drills as though it is well packed or cemented by a soft material. The cement or packing, as the case may be, causes the drill to react much the same as it would in coarse sand. It is believed that packing causes the uniform drill action because no cementing material has been found in any of the drill cuttings. Also, no cementing material is indicated by the electric log of well 79:9-109. The self-potential and resistivity curves are similar to the curves shown on electric logs of other wells in the sands of the Claiborne.

The thickness of the upper part of the lower unit of the Claiborne is known in only four wells. Three of these are test wells in the Allen well field, in which the thickness ranges from 475 feet in well 79:9-109 to about 325 feet in well 79:9-133. The log of B. A. Murrelle, Horton oil test 1 north of Memphis shows a thickness of 300 feet of fine sand but shows also a clay and medium to coarse sand below the fine sand. The total thickness of the lower unit in this well is 560 feet. The lower unit was not recognized in well 24:10-1, but the well $\log$ indicates that there is about 220 feet of fine and fine to medium sand and a few thin clay and lignite beds, which is found at the base of the "500foot" sand and may be equivalent to the lower unit.

Apparently there was erosion after the deposition of the lower unit, creating a relief of as much as 80 or 100 feet in the upper surface. In 18 test wells in the Allen well field the top of this unit ranges from 317 to 239 feet below sea level. In the B. A. Murrelle, Horton oil test 1 , the top is about 300 feet below sea level, and in well 79:8-85 in southeast Memphis it may be as high as 215 feet below sea level.

As the lower unit contains beds of lignite and clay, it probably was deposited in water. No histograms have been made, but the uniformity of grain size and the apparent extensiveness of the deposit indicate that it may be a near-shore or beach sand.

Upper unit (upper part of " 500 -foot" sand). - The upper unit is the part of the "500-foot" sand from which most of the water in the Memphis area is obtained. The outcrop area of this sand has not been mapped, but it is believed to occupy a large part of the area shown as the Grenada formation of the Wilcox group on the latest geologic map of Tennessee (Pond, 1933).

The upper unit is composed of sand, silt, clay, and lignite. Locally, the beds of sand contain flakes of muscovite as much as one-eighth of an inch in diameter. Indurated rocks as thick as 2 feet also are present in this unit. The grain size varies from top to bottom in all wells, but the sands are generally well sorted. Mechanical analyses of 5- and 10-foot samples taken from the "500-foot" sand generally show 85 to 95 percent of the sample on adjoining sieves. Subsurface cross sections in the Allen well field in southwest Memphis, prepared by Armstrong (1954), show that the grain size of the sand varies within comparatively short horizontal distances. Wells' in this field are spaced at intervals of 750 to 1,000 feet, but the sediments at corresponding depths in any two adjacent wells may be greatly different lithologically. Cross sections through the other well fields in Memphis and through individual wells in Shelby and Tipton Counties, Tenn., and in Crittendon County, Ark., indicate that the heterogeneity persists throughout the area.

In Memphis the top of the upper unit ranges from about 100 feet below sea level to about 50 feet above sea level, but its average elevation is approximately at sea level. The bottom ranges from 250 to 300 feet below sea level. The thickness of the unit ranges from 190 to 400 feet but is generally about 275 feet.

Because of the wide variation in the elevation of the top of the unit, the dip was not determined but is believed to be relatively low.

The "500-foot" sand appears to grade into the overlying Jackson(?) formation and the boundary between them is arbitrary. The upper unit of the "500-foot" sand, at least a part of it, may belong to the Jackson(?) formation.

The vertical and horizontal lithologic changes and the relatively poor sorting indicate that the upper unit of the Claiborne group is probably either an alluvial or a deltaic deposit. In an alluvial or deltaic environment clay and silt are deposited in quiet water and sand is deposited in the channels and on parts of the flood plains.

Although there are lithologic differences between the upper and lower units of the Claiborne group, they are believed to constitute a hydrologic unit. Tests have not been made to determine whether there is movement of water from one unit to the other, but the only available record of a well screened in the lower unit shows that the water-level decline is nearly the same as the decline in the upper unit. The lowest sand bed of the lower unit of the " 500 -foot" sand may not be a part of this hydrologic unit, but more information is needed before a separation can be made.

The " 500 -foot" sand is probably continuous from Memphis to its eastern outcrop. If it has a relatively constant thickness and continues eastward at a dip of about 10 feet per mile, its outcrop area should extend from about 20 miles east of Memphis to the outcrop between the Claiborne and Midway contact about 60 miles east of Memphis.

\section{Jackson(?) Formation}

The Jackson(?) formation overlies the " 500 -foot" sand and underlies the Pliocene and Pleistocene terrace deposits. No fossils that would identify this formation have been found under Memphis, and no continuous body of clay has been traced into the Memphis area from clays known to belong to the Jackson formation. A cross section by Fisk (1944) indicates that the Jackson is absent at Memphis.

The Jackson(?) formation consists of dominantly hard dark-bluish- to greenish-gray clay and lignite. Near the bottom the formation generally is more sanciy and grades into the underlying " 500 -foot" sand. 
The elevation of the top of the formation ranges from about 80 to 205 feet above mean sea level, and its thickness ranges from 56 to 300 feet. The Jackson(?) formation forms a confining layer over the "500-foot" sand. In test well 79:9-125 the hard clays of the formation are absent and the confining layer is 56 feet of sandy clay and fine sand.

\section{Pliocene and Pleistocene Terrace Deposits}

The Pliocene and Pleistocene terrace deposits are considered one unit in this report. Glenn (1906) recognized two sand and gravel deposits in outcrops near the Mississippi River, but they cannot be differentiated in the subsurface. He considered one of these deposits to be of Pliocene age and the other of Pleistocene age. Fisk (1944) considers these deposits to be of Pleistocene age.

Most of the terrace deposits are composed of ironstained quartz sand and rounded chert gravel, but they include many cobbles of quartzite, sandstone, jasper, and quartz. Thin lenses of ocher-colored clay are present, more commonly in the lower few feet. Replaced Paleozoic crinoid stems, brachipods, and corals have been found in the deposits. In many test wells the bottom 3 to 48 inches of sand and gravel is cemented with limonite.

The terrace deposits overlie the Jackson(?) formation but appear not to be present throughout the entire area, so that in some places the loess lies directly on the Jackson(?) formation. They parallel the Mississippi River and dip gently from their outcrop in the eastern part of Shelby County to the loess bluffs along the river. Erosion has removed these deposits from the channels of the Mississippi River and the lower part of the Wolf River. Probably other streams in the Memphis area also have cut through them. The deposits are missing in several wells that have been drilled in the area. The maximum recorded thickness of the Pliocene and Pleistocene terrace deposits is 157 feet in test well 79:9-125. Their average thickness is about 40 feet.

Many domestic supplies of ground water are obtained from the terrace deposits.

\section{$\underline{\text { Loess }}$}

The loess is a windblown deposit that blankets most of western Tennessee. It is generally buff colored and massive, and in the Memphis area it is commonly gray near the bottom. Because of its vertical jointing it stands in nearly vertical bluffs in eroded areas. Its texture is uniform. It is composed predominantly of angular silt-size grains of quartz and some grains of feldspar and clay minerals. It contains limonitic concretions commonly in the lower few feet. The thickness of loess penetrated in most wells in the Memphis area is generally less than 40 feet. The loess does not furnish water to any wells in the area.

\section{Alluvium}

Alluvial deposits are found in all the larger stream valleys in the area. The Mississippi River has a valley about 35 miles wide at Memphis, whereas its larger tributary streams, Nonconnah Creek, Wolf River, and Loosahatchie River, which traverse the area, have valleys from $1 / 2$ to $21 / 2$ miles wide.

Fisk (1944) shows on his cross section near Memphis that the alluvium has a maximum thickness of about 200 feet. His map indicates that there is as much as 150 feet of alluvium in the lower parts of the larger tributaries.

In grain size the alluvial deposits range from silt to fine gravel. Lignite, peat, and other carbonaceous matter are distributed irregularly throughout the alluvium. The coarsest material is generally found near the present stream channels, and the finest near the featheredge of the deposits.

\section{GROUND WATER}

Water below the surface of the ground which is in the zone of saturation, and which therefore is available to wells or springs, is termed "ground water." In the Memphis area most of the ground water is derived from precipitation that falls on the outcrop area or on adjacent areas. Most of the water that falls as precipitation evaporates, is used by vegetation, and is carried away as surface runoff, but a small fraction of it enters the ground and eventually joins the body of ground water.

Ground water moves from the areas of recharge toward areas of natural or artificial discharge. The rate of movement depends in part upon the hydraulic gradient represented by the slope of the water table or of the piezometric (pressure-head-indicating) surface. The water table is defined as the upper surface of the zone of saturation except where that surface is formed by an impermeable body (Meinzer, 1923), in which case the water table is absent and artesian conditions exist. Under artesian conditions water is confined within the water-bearing formation by relatively impermeable beds and will rise, in a well drilled through the confining layer, to a level above the waterbearing formation that depends on the pressure head. The piezometric surface is the imaginary surface representing the height to which the water will rise in wells tapping an artesian aquifer. The water table or the piezometric surface is not a plane surface but a sloping one that may have irregularities. Also, it is not stationary, but fluctuates in response to additions to, or withdrawals from, water in storage and to other factors such as changes in barometric pressure.

The configuration of the water table or piezometric surface is shown by means of contour lines, similar to those which show the shape of the land surface on topographic maps. The direction of movement of ground water is at right angles to the contour lines. 
AVERAGE PUMPAGE, IN MILLION GALLONS PER DAY

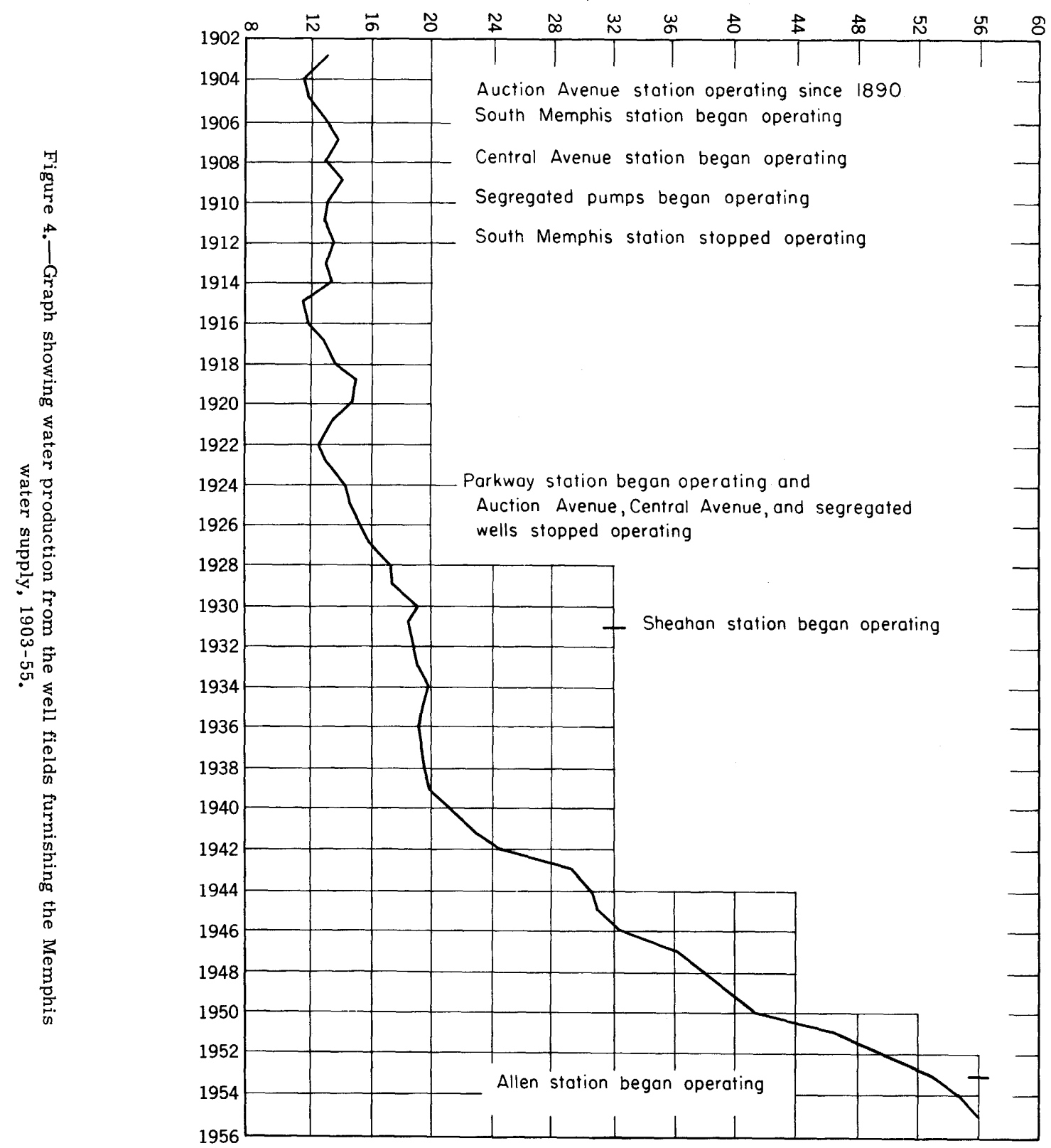


"1,400-foot" Sand

History of Development

The entire municipal water supply of Memphis, Tenn., comes from water-bearing sands of Eocene age. Most of the water is obtained from sandy beds about 250 to 600 feet below the land surface in the Claiborne group which are a part of the " 500 -foot" sand, but some of it is obtained from a sand about 1,200 to 1,400 feet below the land surface in the Wilcox group, known locally as the "1,400-foot" sand.

An exploratory test hole that reached the "1,400foot" sand was drilled in 1902, but it was not until 1924 that a supply well tapping this sand was drilled by the Board of Water Commissioners (now the Memphis Light, Gas, and Water Division). By 1928 the city had 9 wells in this sand. At present the city uses 18 wells screened in this stratum, and the Buckeye Cotton Oil Co. uses 3. From 1940 to 1945 a well screened in this sand was pumped at the Chickasaw Ordnance Works about 15 miles north of Memphis.

West Memphis, Ark., about 7 miles west of Memphis, uses 4 wells in the "1,400-foot" sand, and Marion, Ark., about 5 miles north of West Memphis, uses 2. Several 2- and 3-inch wells that probably tap the same sand are reported south of Memphis in De Soto County, Miss.

In 1949 the U. S. Geological Survey, in cooperation with the Tennessee Division of Geology, completed an observation well in the "1,400-foot" sand near Braden, Fayette County, about 30 miles east of Memphis. This well is 1 of 4 in this sand presently used for waterlevel observation.

\section{Pumpage}

So far as is known the only large withdrawals of water from the "1,400-foot" sand in the Memphis area are those in Shelby County. Figure 4 shows the history of water production from the well fields furnishing the Memphis public water supply. A partial well inventory in Crittenden County, Ark., indicates that the total withdrawal in that county at present (1955) is slightly more than $1 \mathrm{mgd}$. The quantity of water withdrawn from the 2- and 3-inch wells penetrating the sand in De Soto County, Miss., is small. It is estimated that outside Shelby County the total amount of water pumped from the "1,400-foot" sand in 1955 was less than $11 / 4$ mgd. Figure 5 includes a graph showing the pumpage from this sand.

According to Schneider and Cushing (1948) it has been possible to collect an almost complete record of the water pumped from the aquifer. The estimated average daily pumpage is given in table 1 , beginning at the time the first well was put into operation by the city of Memphis on November 11, 1924.

\section{Water Leve1}

Schneider and Cushing (1948) believed that the water level of the "1,400-foot" sand in the Memphis area was about 244 feet above mean sea level before pumping began. Systematic records of water levels in
Table 1.-Average daily pumpage, in million gallons, from the "1,400-foot" sand in the Memphis area

\begin{tabular}{r|r|r|r|r|r}
\hline Year & Pumpage & Year & Pumpage & Year & Pumpage \\
\hline 1924 & 0.1 & 1935 & 6.3 & 1946 & 8.9 \\
1925 & .9 & 1936 & 5.4 & 1947 & 10.3 \\
1926 & 2.5 & 1937 & 4.5 & 1948 & 10.9 \\
1927 & 2.2 & 1938 & 5.6 & 1949 & 13.8 \\
1928 & 4.6 & 1939 & 6.0 & 1950 & 14.1 \\
1929 & 5.7 & 1940 & 6.8 & 1951 & 15.1 \\
1930 & 6.2 & 1941 & 8.8 & 1952 & 11.9 \\
1931 & 5.4 & 1942 & 8.8 & 1953 & 12.7 \\
1932 & 6.5 & 1943 & 11.2 & 1954 & 12.6 \\
1933 & 3.8 & 1944 & 10.9 & 1955 & 13.4 \\
1934 & 4.9 & 1945 & 8.9 & & \\
\hline
\end{tabular}

wells penetrating the sand are not available for the period 1924-44, principally because all the wells were being pumped and no unused wells were available in which measurements could be made. Periodic waterlevel measurements were started in January 1945 in well 7-26 in north Memphis. Figure 6 shows the graph of the lowest annual water level in this well since 1945 .

\section{Pumping Tests}

The quantity of water that can be obtained from a well or a group of wells depends in part upon the hydraulic characteristics of the water-bearing formation tapped by the wells. Pumping tests may be used to determine these characteristics. The quantity of water which is transmitted by an aquifer depends upon its permeability and thickness and on the hydraulic gradient.

The permeability (P) of an aquifer is the rate at which the aquifer will transmit water through a unit cross section under a unit hydraulic gradient. In the Geological Survey it is expressed in meinzers (gallons per day per, square foot at $60^{\circ} \mathrm{F}$ ). The field permeability is the same except that it is measured at the prevailing temperature of the water rather than at $60^{\circ} \mathrm{F}$.

The coefficient of transmissibility $(T)$ is the product of the field permeability, and the thickness, in feet, of the saturated portion of the aquifer, is expressed in gallons per day per foot.

The coefficient of storage (S) of an aquifer is the volume of water it releases from, or takes into, storage per unit surface area of the aquifer per unit change in the component of head normal to that surface.

Pumping tests in the " 1,400 -foot" sand were run in the Parkway well field, in the Sheahan well field, and at the Buckeye Cotton Oil Co. on Jackson Avenue. From these tests, coefficients of transmissibility and storage were obtained. The average coefficient of transmissibility of the "1,400-foot" sand, obtained by averaging the separate computations for $T$ was about $115,000 \mathrm{gpd}$ per foot; the average coefficient of storage was about 0.0003 . 


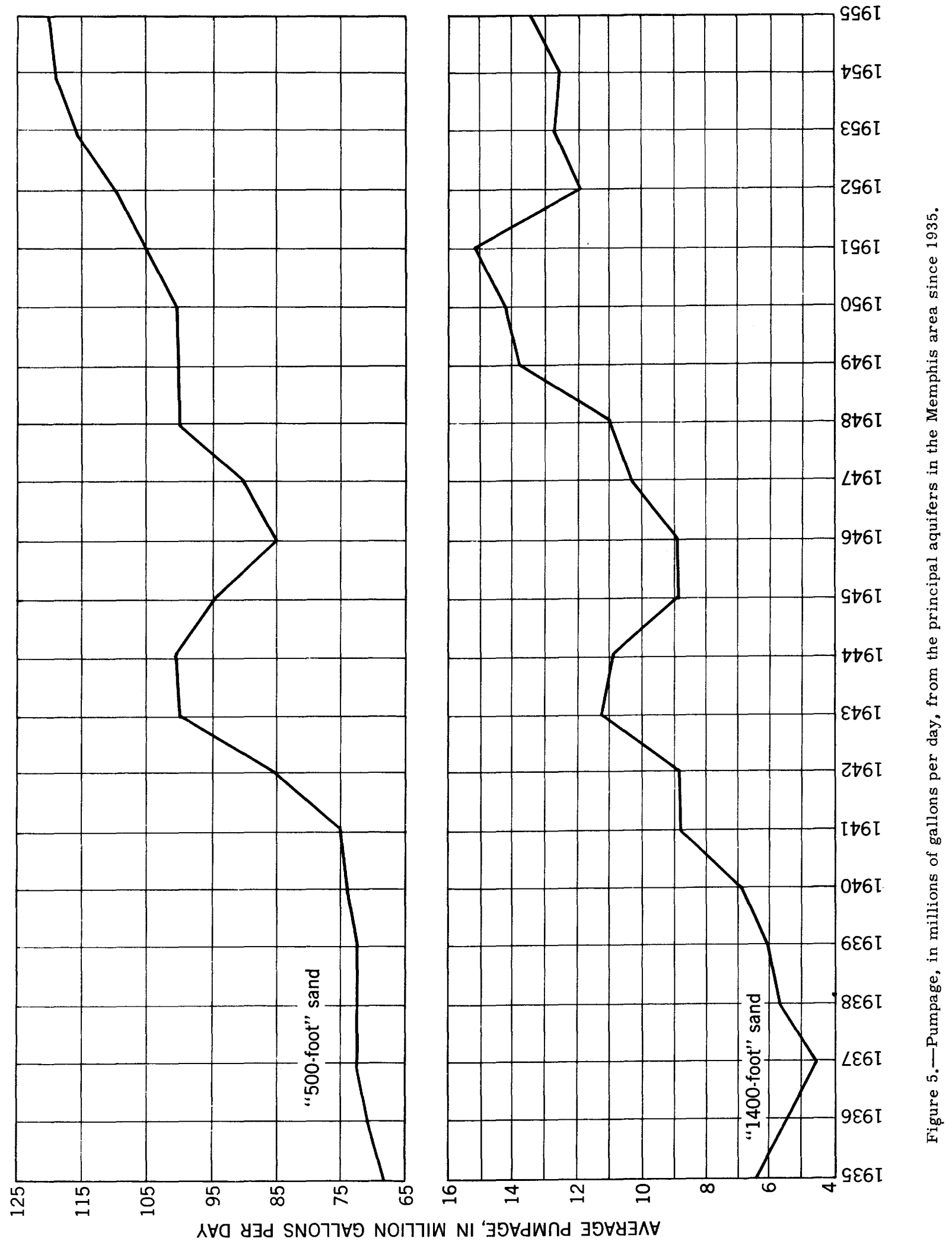




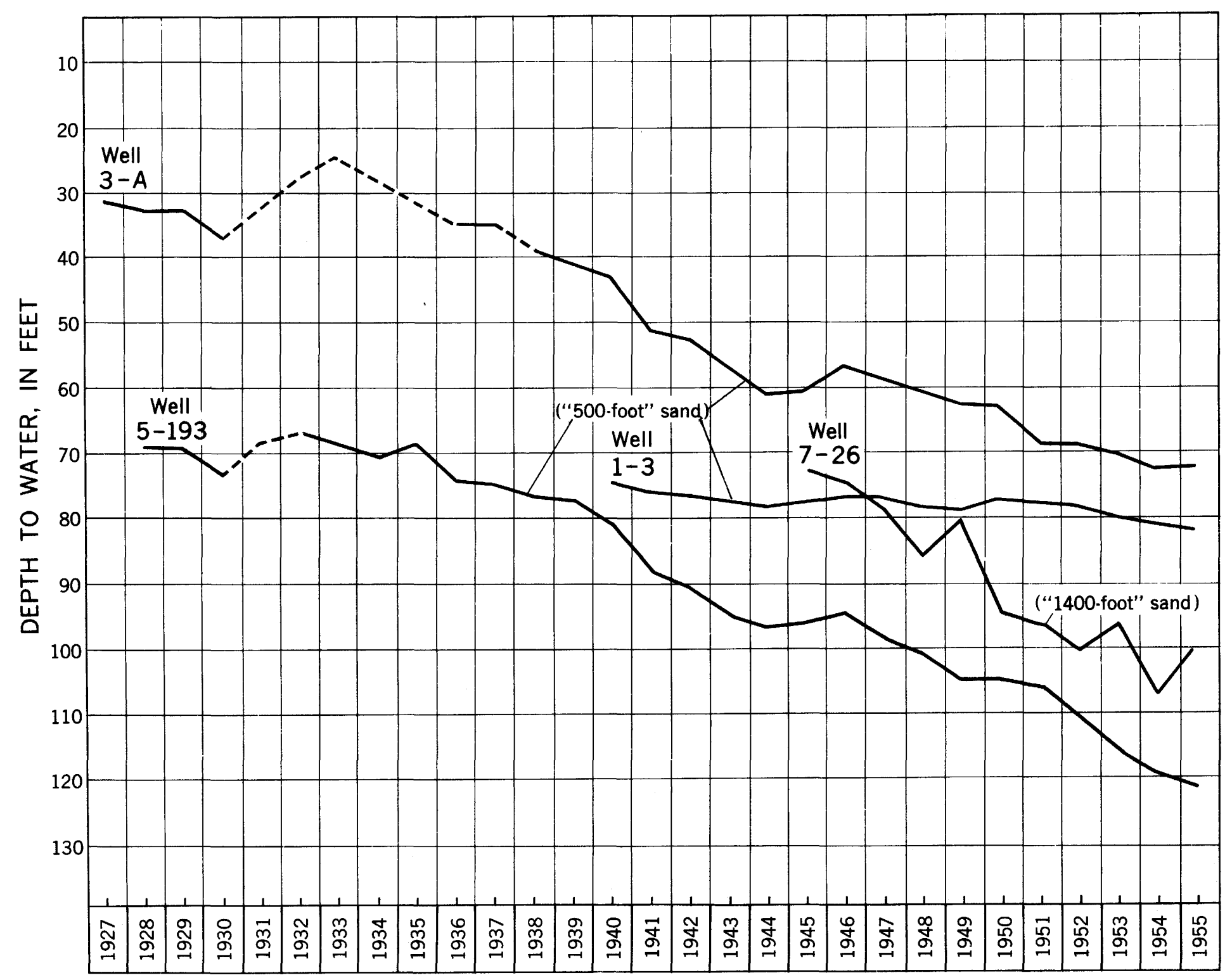


The table below presents the average results obtained from these pumping tests.

Figure 7 shows the computed drawdown in the "1,400-foot" sand at the end of 1 day at various distances from a well being pumped at a rate of 1,000 gpm (gallons per minute). The curves are based on the highest and lowest values of the coefficients of transmissibility and storage that were observed, and thus show the maximum and minimum drawdowns that might occur if these values represent the extreme range in the coefficients in this area. The test computations, and the construction of figures 7 and 8 , are based on the assumption that there is no rècharge and thus that all the water comes from storage.

\begin{tabular}{|c|c|c|c|c|}
\hline Location & $\begin{array}{l}\text { Number } \\
\text { of sets } \\
\text { of data }\end{array}$ & $\begin{array}{l}\text { Average } \\
\text { transmissibility } \\
\text { (gallons per day } \\
\text { per foot) }\end{array}$ & $\begin{array}{l}\text { Number } \\
\text { of sets } \\
\text { of data }\end{array}$ & $\begin{array}{l}\text { Average } \\
\text { coefficient } \\
\text { of storage }\end{array}$ \\
\hline Sheahan well field & 14 & 100,000 & 12 & 0.00016 \\
\hline 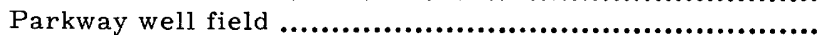 & 5 & 130,000 & 4 & .00045 \\
\hline Buckeye Cotton Oil Co............................................. & 2 & 100,000 & 2 & .00023 \\
\hline
\end{tabular}

\section{Chemical Quality}

Water from the "1,400-foot" sand is generally of good quality. It ranges in temperature from $70^{\circ}$ to $72^{\circ} \mathrm{F}$. The average hardness (as $\mathrm{CaCO}_{3}$ ), determined from available analyses, is about $10 \mathrm{ppm}$ (parts per million). The maximum hardness recorded is $17 \mathrm{ppm}$ and the minimum is $5 \mathrm{ppm}$.

Among the constituents of water that cause some difficulty in the Memphis area are iron and free carbon dioxide $\left(\mathrm{CO}_{2}\right)$. The water contains an average of about $1.3 \mathrm{ppm}$ of iron and about $15 \mathrm{ppm}$ of free carbon dioxide. These objectionable constituents can be substantially removed by aeration and filtration of the water. Practically all the iron and carbon dioxide are removed from the public supply of Memphis in this manner.

The carbon dioxide and $\mathrm{pH}$ determinations shown in table 2 may not be reliable because they were made several days to several weeks after the samples of water were collected. Free carbon dioxide begins to escape from the water immediately upon exposure to the atmosphere or pressure decrease and a loss of carbon dioxide from the water results in a rise in the $\mathrm{pH}$.

Table 2 contains typical chemical analyses of water from the "1,400-foot" sand. A comparison of analyses of samples collected in 1925 and 1927 with those collected during this investigation show the constancy of quality of the water?

Table 2.-Typical chemical analyses of water from the "1,400-foot" sand

[A, analysis in U. S. Geological Survey; B, analysis by F. A. Mantel, Memphis Water Department. Chemical constituents in parts per million]

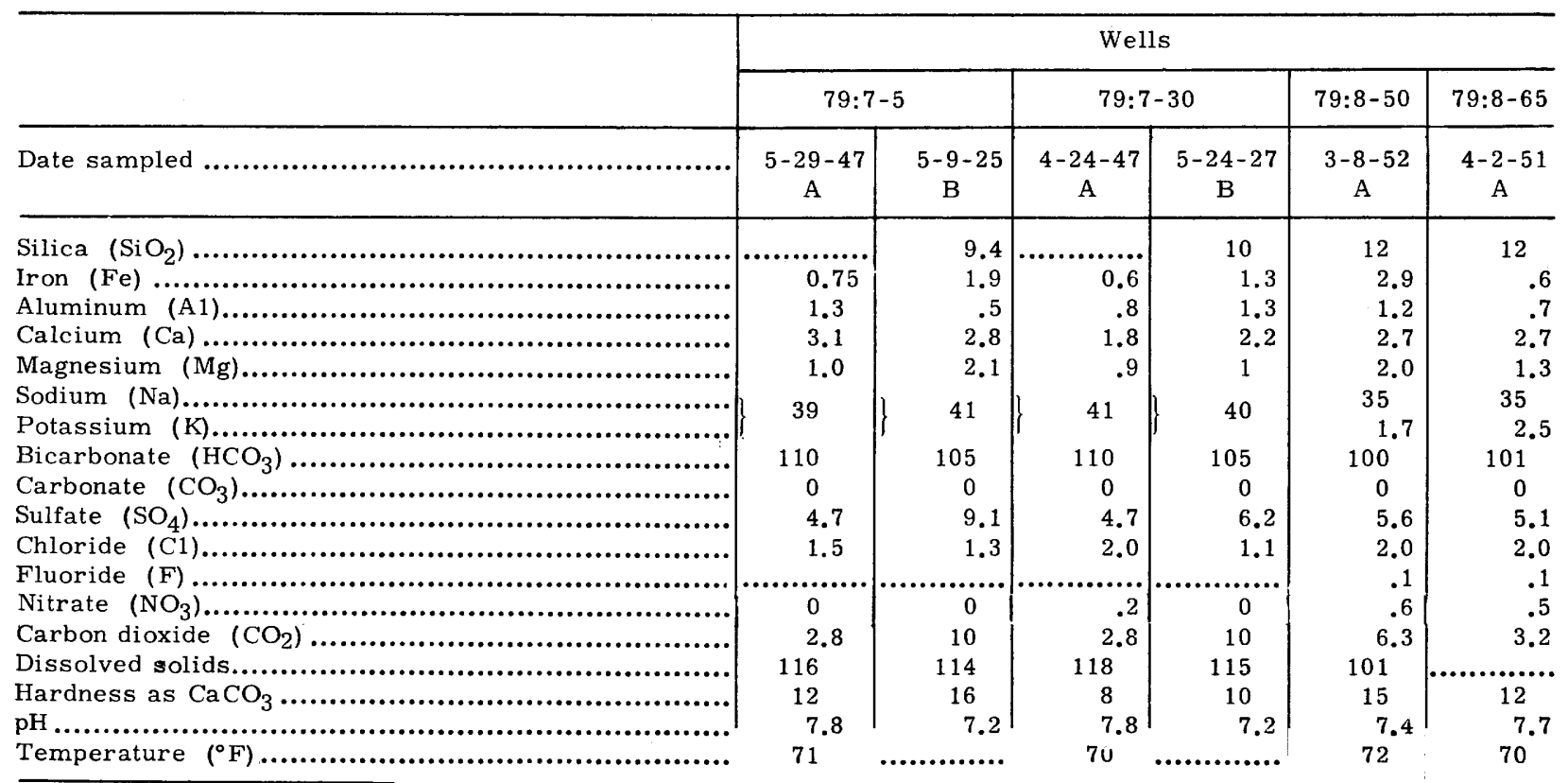




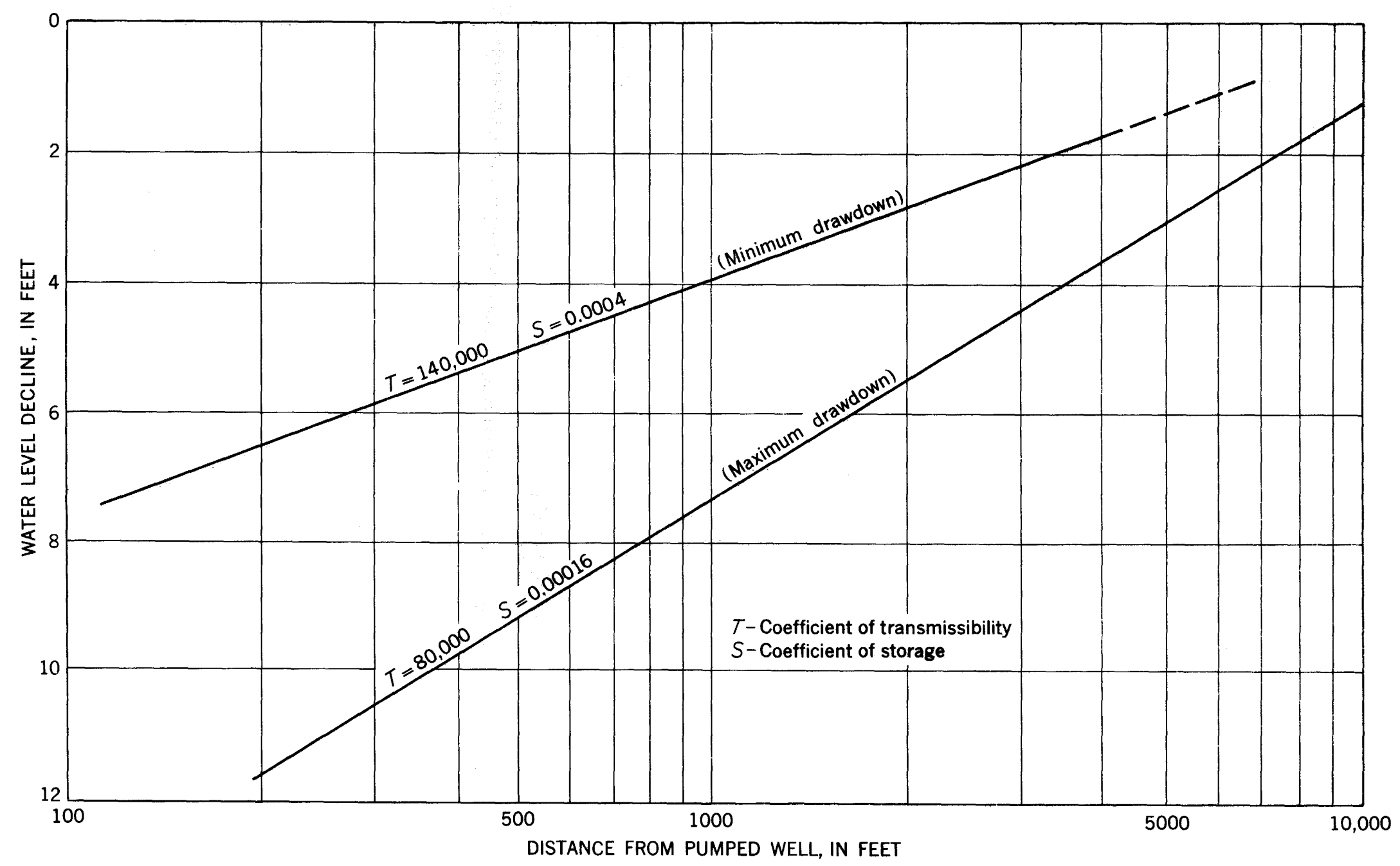

妏

Figure 7.-Drawdowns to be expected in the "1,400-foot" sand at the end of 1 day at various distances from a well being pumped at 1,000 gallons per minute. 
"500-foot" Sand

History of Development

Before 1870 the terrace deposits and cisterns were the only sources of water supply for the Memphis area. Thereafter, this supply was supplemented for a time by water pumped from the Wolf River. The water from the river was untreated and often was very turbid, however, and hence there was a demand for an improved public water supply. In 1886 the first well tapping the "500-foot" sand was drilled. The water was tested and found to be good. Within 3 years after this first successful well was drilled, according to Safford (1890), 57 wells deeper than 185 feet had been drilled in the city.

At present (1955) most of the municipal supply of Memphis, as well as the public supplies for Arlington, Collierville, Frayser, Germantown, Raleigh, and Whitehaven, come from the " 500 -foot" sand. Many domestic wells in the eastern part of the area are screened in this sand, and practically all the industries in the area that have wells obtain water from it. The Memphis municipal supply includes more than 100 wells and the industrial supplies about 200. About 90 percent of the water used in the Memphis area is pumped from the " 500 -foot" sand.

Industry has led in the development of wells in the " 500 -foot" sand since the first exploratory well was drilled in 1886. Records of the development by industries are scarce, but each inventory of wells has shown that industrial pumpage has been greater than the municipal pumpage in the area.

\section{Pumpage}

Kazmann (1944) stated the following important facts about pumping in the Memphis area: (a) Most of it takes place in a rather small area, (b) it increased steadily during the 15 years preceding his report $(1929-44)$, and (c) it increased greatly after 1940 . Presently (1955), pumping is still concentrated within the city, though one recently constructed municipal pumping station and the sites of two proposed ones are several miles from the area that was heavily pumped in 1944. The pumping rate is still increasing as a result of municipal and industrial growth in the area, and probably it will continue to increase each year.

The pumpage decreased for a while after World War II, but by 1952 it had exceeded the maximum attained during the war. By 1955 the average daily pumpage had risen to a total of about 20 million gallons greater than the peak pumpage during World War II.

Pumpage from the "500-foot" sand cannot be estimated as accurately as that from the "1,400-foot" sand. Nearly all the municipal pumpage and about half the industrial pumpage in the area is metered and reported each month, but the remainder must be estimated. Figure 5 shows the average daily pumpage from the "500-foot" sand. It is estimated that the maximum daily pumpage in the area may exceed the average by as much as 50 percent, that is, may have been as great as about 180 million gallons on days of maximum demand in 1955 .
The amount of water used for irrigation has risen considerably since 1952. Several irrigation wells in Mississippi within the Memphis area are screened in the "500-foot" sand. There were 27 irrigation systems using ground water in Shelby County in 1955. Irrigation pumpage varies from year to year and is difficult to estimate, but it may have ranged from about $1 / 2$ to $5 \mathrm{mgd}$ in the summers of $1952-55$.

Figure 4 shows the history of water production from the well fields of the Memphis public water supply.

\section{Water levels}

Wells (1931), in his preliminary report on the artesian water supply of Memphis, states that the original static water level in the " 500 -foot" sand in the vicinity of the Auction Avenue wells was probably about 235 feet above mean sea level. Since Wells' report was published, records of the water-level fluctuations in wells 3-A and 5-193 have been maintained almost continuously by city personnel and others. In 1940 the Memphis Light, Gas, and Water Division began a program of water-level measurements in cooperation with the U. S. Geological Survey. It was planned at that time to drill 8 observation wells spaced at about equal distances on a circle about 8 miles from the center of the city. Only 4 wells have been drilled, 1 north, 1 northeast, 1 east, and 1 southeast of the city. Upon completion, each of these wells was equipped with a recording gage from which a continuous record of the water-level fluctuations has been obtained. Since 1940, additional wells have been added to the water-level measurement program, so that in 1955 water levels were being measured in 48 wells in Shelby County, 26 of which were equipped with recording gages.

Kazmann (1944) determined that the average rate of decline in the water level in well 3 -A was 1.0 foot per year in the period $1929-40$ and 4.4 feet per year in the period 1940-43. In the same periods the average rate of decline in the water level in well 5-193 was 1.2 and 4.3 feet per year, respectively. The water levels in these two wells generally show the long-term effects of pumping, but not so much the short-term effects of daily changes in pumping.

Tabulated below are the average rates of waterlevel decline in wells 3-A and 5-193 for the periods indicated.

Average rate of decline (feet per year)

Well 3-A

$1929-1940$

1.0

$1940-1943$

$1943-1955$

4.4

$1929-1955$

Well 5-193

$1929-1940$

$1929-1955$

2.2

The decline of 4.4 feet per year during the period 1940 to 1943 reflects the increase of pumping during World War II. 
Pumping in the area has recently been distributed over a larger area by the addition of the Thomas $\mathrm{H}$. Allen pumping station to the Memphis public supply. The average daily pumpage from this new station has doubled approximately each succeeding year since its completion in 1952. The water-level decline in Memphis since that time has not been as great except in the vicinity of the new station.

The average decline of water levels in 5 observation wells in the Thomas H. Allen well field is as follows:

$\begin{array}{rrr} & \text { Feet } \\ 1952-53 & \ldots \ldots \ldots \ldots & 21 \\ 1953-54 & \ldots \ldots \ldots \ldots & 11 \\ 1954-55 \ldots \ldots \ldots \ldots & 5\end{array}$

The average annual decline during the 3 years of record is about 12 feet. Although pumpage doubled each year from 1952 to 1955 , the decline in each succeeding year decreased by about half. It is expected that the rate of water-level decline will continue to decrease. Wells of the new station were pumped at nearly maximum capacity in 1955 .

Figure 6 shows the annual low water levels in selected observation wells screened in the "500-foot" sand.

\section{Pumping Tests}

Several pumping tests have been made in municipal wells screened in the " 500 -foot" sand. The computed values of $T$ range from about 100,000 to $420,000 \mathrm{gpd}$ per foot and those of $\underline{S}$ from 0.00024 to 0.0027 . Figure 8 shows the maximum and minimum drawdowns that may be expected at the end of 1 day at various distances from a well in the " 500 -foot" sand being pumped at the rate of $1,000 \mathrm{gpm}$. As in figure 7 , the curves are based on the highest and lowest observed values of $T$ and $S$. The test computations and the curves shown in figure 7 are based on the assumption that all the water comes from storage. It was observed, however, during several of the tests in which pumping was continued for more than 3 days, that the water levels in some of the observation wells near the pumped well ceased to decline. One possible explanation for this condition is that additional water from a source outside the aquifer had been captured. The most logical source of this water is the terrace deposits overlying the " 500 -foot" sand and separated from it by the Jackson(?) formation. Additional information which tends to indicate that water may come from the terrace deposits through the confining bed was found during a test in east Memphis. Before this test, the water level in the terrace deposits was rising, but, within 2 hours after pumping was begun from wells in the " 500 -foot" sand, the water level in the terrace deposits began to decline and continued to decline until pumping from the " 500 -foot" sand was stopped. None of the tests was continued long enough for water levels in all wells in the " 500 -foot" sand to stabilize.

No tests have been made specifically to determine whether leakage occurred. Substantial leakage from the terrace deposits may not occur over the entire area.
Each year since the tests were made the observed water levels in the " 500 -foot" sand were higher than the computed water levels. This discrepancy is attributed primarily to the assumption in the computations that the aquifer receives no additional recharge or capture as a result of the pumping. Also, the facts that the "500-foot" sand is not homogeneous and isotropic and that none of the wells completely penetrates this aquifer may be responsible in part for the discrepancy. In effect, the " 500 -foot" sand produces a greater amount of water at a given drawdown than the computed values of $\mathrm{T}$ and $\underline{S}$ indicate that it should.

\section{Chemical Quality}

Water from the "500-foot" sand is of good quality. It ranges in temperature from $61^{\circ}$ to $64^{\circ} \mathrm{F}$. The average hardness (as $\mathrm{CaCO}_{3}$ ), determined from available analyses, is about $40 \mathrm{ppm}$. The maximum hardness determined is $60 \mathrm{ppm}$ and the minimum is 10 . The hardness of water from wells near Millington is considerably higher, probably as a result of leakage from adjacent aquifers carrying hard water.

Constituents of the water that cause difficulty are iron, free carbon dioxide, and, in some places, hydrogen sulfide. The water contains an average of about $0.8 \mathrm{ppm}$ of iron, ranging from a maximum of $1.7 \mathrm{ppm}$ to a minimum of 0.05 . The content of free carbon dioxide in some of the water may be as much as $100 \mathrm{ppm}$. Hydrogen sulfide has been measured in amounts as high as $0.4 \mathrm{ppm}$.

The $\mathrm{pH}$ is generally between 5.9 and 6.3 , though in some samples it is as low as 5.3 and in others as high as 7.3. Because of the high content of free carbon dioxide, it is necessary to determine the $\mathrm{pH}$ in the field to obtain a correct value.

Table 3 contains typical chemical analyses of water from 5 wells screened in the " 500 -foot" sand. Some of the $\mathrm{pH}$ values in this table may not be reliable because of the time elapsed between sample collection and analysis.

\section{Terrace Deposits}

Except for yielding water to many domestic and farm wells, little is known of the water-bearing character of the terrace deposits in the Memphis area. Drillers' logs indicate that the deposits are missing in some parts of the area.

The terrace deposits originally were the source of ground water for domestic use in Memphis and are still the major source for domestic and farm use outside the city. A few wells in Memphis screened in the terrace deposits supply water for swimming pools, irrigation, and industries, but none are used for domestic purposes in any part of the city. Most of these wells are so small in diameter that they cannot be used as observation wells.

Water from tho terrace deposits generally is hard but commonly contains less iron and carbon dioxide than the water from either the " 500 -foot" or the 


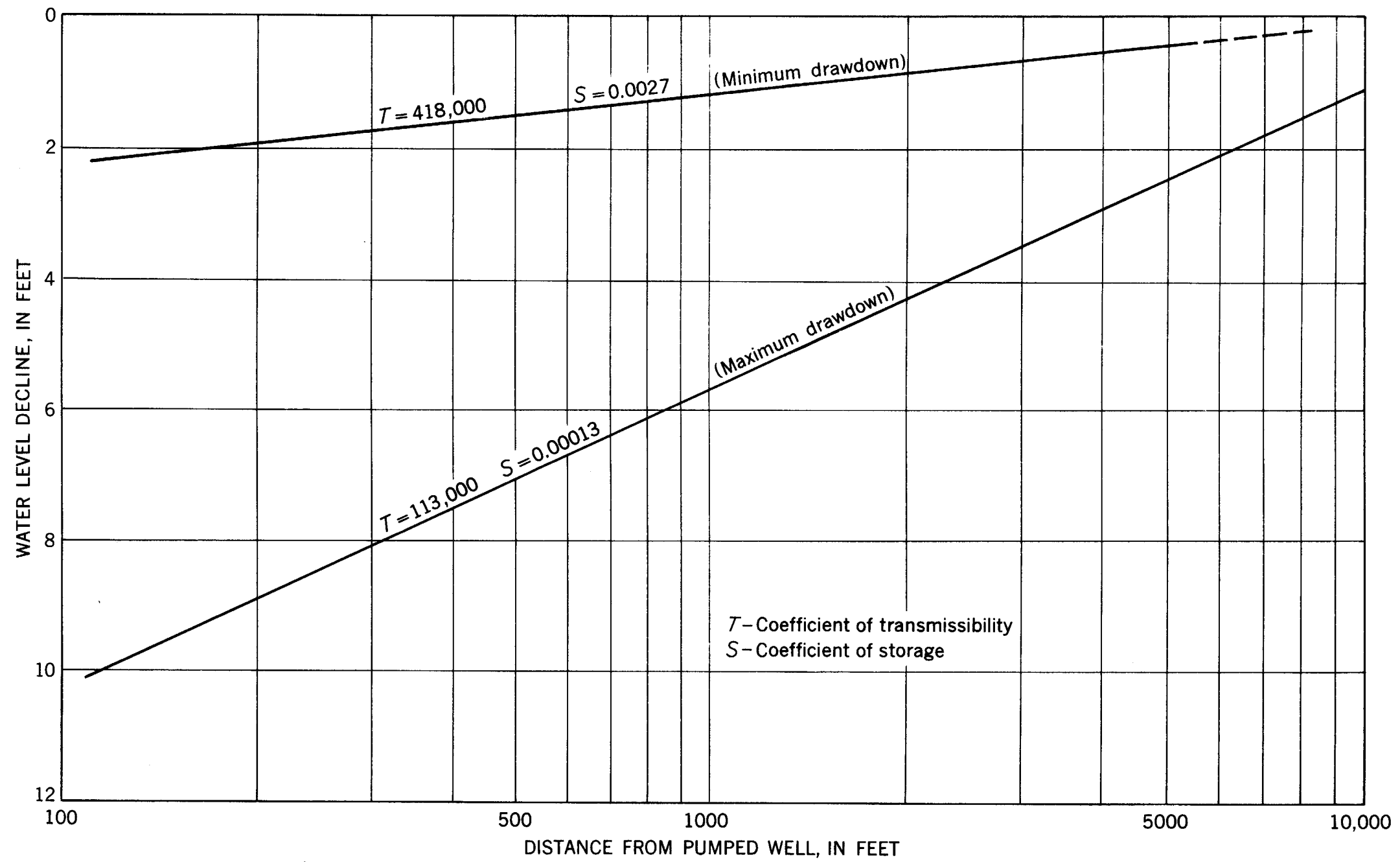

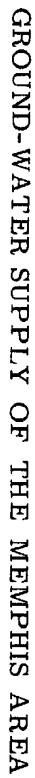

Figure 8. -Drawdowns to be expected in the "500-foot" sand at the end of 1 day at various distances from a well being pumped at 1,000 gallons per minute. 
Table 3.-Typical chemical analyses of water from the " 500 -foot" sand

[Analyses by U. S. Geological Survey. Chemical constituents in parts per million]

\begin{tabular}{|c|c|c|c|c|c|}
\hline & \multicolumn{5}{|c|}{ Wells } \\
\hline & $79: 7-23$ & $79: 7-39$ & $79: 8-51$ & $79: 8-59$ & $79: 8-63$ \\
\hline 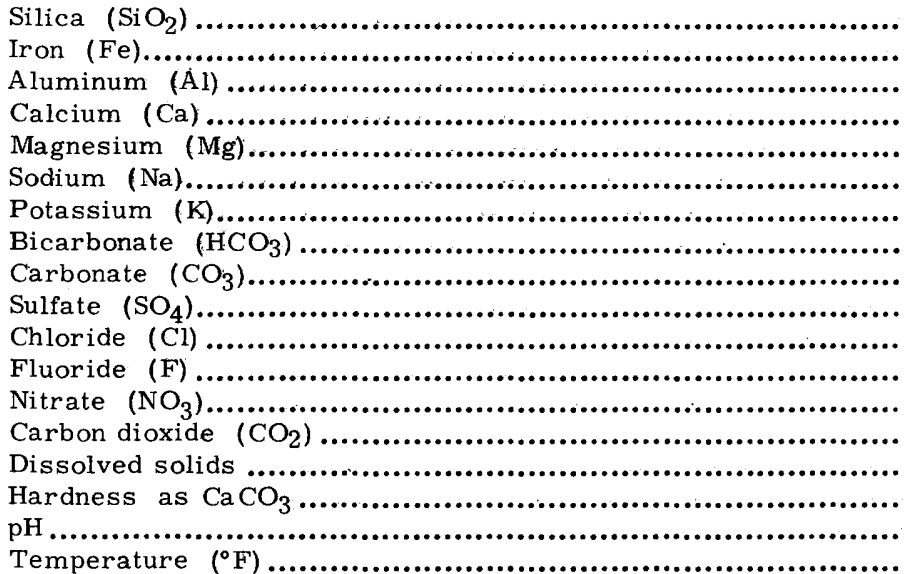 & $\begin{array}{l}.4 \\
.6 \\
11 \\
5.6 \\
9.2 \\
.9 \\
78 \\
0 \\
3.1 \\
3.0 \\
.1 \\
.3 \\
16 \\
85 \\
50 \\
6.9 \\
62\end{array}$ & $\begin{array}{c}14 \\
1.0 \\
\ldots \ldots \ldots . . \\
12 \\
6.0 \\
9.4 \\
.8 \\
88 \\
0 \\
3.4 \\
2.5 \\
.1 \\
0 \\
88 \\
87 \\
55 \\
6.2 \\
62\end{array}$ & $\begin{array}{c}11 \\
1.0 \\
1.3 \\
8.5 \\
4.3 \\
7.8 \\
.9 \\
54 \\
0 \\
4.4 \\
4.2 \\
.1 \\
1.2 \\
86 \\
66 \\
39 \\
6.0 \\
63\end{array}$ & \begin{tabular}{c}
13 \\
.2 \\
.5 \\
6.7 \\
3.6 \\
12 \\
\multicolumn{2}{c}{.6} \\
51 \\
0 \\
5.8 \\
6.0 \\
.1 \\
1.1 \\
10 \\
76 \\
32 \\
6.9 \\
61
\end{tabular} & \begin{tabular}{c}
17 \\
.8 \\
$\ldots \ldots . .$. \\
7.0 \\
3.2 \\
11 \\
\multicolumn{2}{c}{.7} \\
49 \\
0 \\
7.8 \\
5.6 \\
.1 \\
.1 \\
78 \\
75 \\
31 \\
5.9 \\
62
\end{tabular} \\
\hline
\end{tabular}

"1,400-foot" sand. The average hardness of the few samples that have been analyzed is about $200 \mathrm{ppm}$.

\section{Alluvium}

As the alluvium is confined to narrow strips along the principal streams in the area and is subject to flooding or is not easily accessible, and as water of good quality is easily obtained from other aquifers, there has been little reas on for the development of wells in alluvium east of the Mississippi River. However, in the portion of the area in Arkansas several irrigation and domestic wells tap the alluvium. The alluvium has the capacity to yield large quantities of water.

There are no chemical analyses of water from the alluvium. The amount of water pumped and its various uses are not known.

\section{CONCLUSION}

The two principal aquifers in the Memphis area are the "500-foot" and " 1,400 -foot" sands. The " 500 -foot" sand was the source of about 90 percent of the ground water used in the area as of 1955. The development of wells in the "1,400-foot" sand is restricted by higher cost and also by an ordinance which controls drilling to all sands within the city. The quality of water from both sands is considered good. The terrace deposits constitute an important source of water for small industrial and domestic supplies in the suburban area. The alluvium furnishes water to a few wells and has the capacity to yield large quantities of water, but it has not yet been developed extensively.
The water level in well 3-A in the "500-foot" sand declined from a reported altitude of about 235 feet, approximately at the land surface, in 1890 to about 72 feet below the land surface in 1955 .

Little information is available outside the Memphis area on the " 500 -foot" and "1,400-foot" sands as identifiable units. Records indicate that a few irrigation wells and several municipal supply wells in western Tennessee probably tap the "500-foot" sand, but substantiating data are not available. It is believed that several municipal supply wells in Arkansas are screened in the "1,400-foot" sand. No detailed investigations of these aquifers have been made outside the Memphis area.

Drillers' logs indicate that neither the " 500 -foot" nor the "1,400-foot" sand is uniform in thickness or composition. Grain size and thickness of the aquifers vary considerably over short distances. There are many clay beds in each sand but they are apparently discontinuous. The presence of clay in the aquifers tends to reduce the transmissibility, but the transmissibility is high because of the great thickness of sand.

Pumping tests were made to determine aquifer characteristics. Some of the tests indicated that the " 500 -foot" sand is recharged by leakage from the terrace deposits.

The potential yield of ground water in the area is much greater than the present withdrawal, but continuing investigation and sound development will be necessary to obtain the maximum benefit from the aquifers and to avoid excessive local drawdowns. 
Water levels have declined at an increasing rate since 1940 because of large increases in pumping. Records indicate that the water level would become nearly stable within a few years if pumping did not increase.

The present program of collection and interpretation of basic water-resources data is adequate for present needs, but it has not continued long enough to provide a basis for evaluating the adequacy of the groundwater resources of the area over the long term. Additional studies leading to a more comprehensive report are planned.

\section{REFERENCES CITED}

Armstrong, C. A., 1954, Memorandum on the postPaleocene subsurface stratigraphy of the Memphis area, Tenn.: U. S. Geol. Survey open-file report.

Brown, G. F., 1947, Geology and artesian water of the alluvial plain in northwestern Mississippi: Mississippi Geol. Survey Bull. 65.

Fisk, H. H., 1944, Geological investigation of the alluvial valley of the lower Mississippi River: Vicksburg, Miss., Mississippi River Comm.

Glenn, L. C., 1906, Underground waters of Tennessee and Kentucky west of Tennessee River and of an adjacent area in Illinois: U. S. Geol. Survey Water-Supply Paper 164.

Kazmann, R. G., September 1944, The water supply of the Memphis area: U. S. Geol. Survey open-file report.

Krumbein, W. C., and Sloss, L. L., 1951, Stratigraphy and sedimentation: San Francisco, Calif., W. H. Freeman \& Co.

Meinzer, O. E., 1923, Outline of ground-water hydrology, with definitions: U. S. Geol. Survey Water-Supply Paper 494.

Pond, Walter F., 1933, Geologic map of Tennessee: Tennessee Div. Geology, 4th ed., scale 1:500,000.

Safford, J. M., 1890, The water supply of Memphis: Tennessee Board Health Bull., v. 5, no. 7.

Schneider, Robert, and Blankenship, R. R., 1950, Subsurface geologic cross section from Claybrook, Madison County, to Memphis, Shelby County, Tenn.: Tennessee Div. Geology, Ground-Water Inv. Prelim. Chart 1.

Schneider, Robert, and Cushing, E. M., 1948, Geology and water-bearing properties of the "1,400-foot" sand in the Memphis area: U. S. Geol. Survey Circ. 33.

Stearns, R. G., and Armstrong, C. A., 1955, Post-Paleozoic stratigraphy of western Tennessee and adjacent portions of the upper Mississippi embayment: Tennessee Div. Geology Rept. Inv. 2.

Wells, F. G., 1931, A preliminary report on the artesian water supply of Memphis, Tenn.: U. S. Geol. Water-Supply Paper 638-A. 1933, Ground-water resources of western Tennessee: U. S. Geol. Survey Water-Supply Paper 656. 